\title{
ОЦНЮВАННЯ СТУПЕНЯ КОМФОРТНОГО ТИСКУ ВЕРХУ ВЗУТТЯ НА СТОПУ СПОЖИВАЧА
}

3 проведеного аналізу антропометричних досліджень стоп і суб'єктивного відчуття зручності взуття показано доречність удосконалення алгоритму моделювання взуття за індивідуальним замовленням за допомогою використання «макета-трансформера взуття». Дані дослідження дають можливість дослідити суб'єктивні відчуття комфорту стопи у взутті, i спрогнозувати забезпечення виготовлення високої якості взуття закритого типу за індивідуальним замовленням за допомогою прототипу - трансформера взуття на базі використання комп'ютерної установки Arduіпо Unо. B роботі досліджено рівень суб'єктивного комфортного тиску верху взуття на стопу людини у статиці та різних фазах ходьби. Приведено дослідження двофакторного експерименту залежності параметрів тиску у антропометричних точках підйому та висоти п'ятки стопи. Одержано рівняння регресії залежності рівня комфорту взуття. Експериментальним иляхом досліджено деформаційні властивості деталі союзки взуття, та отримані лінійні параметри коригування союзки різних повнот колодки для виготовлення взуття за індивідуальним замовленням. Враховуючи отримані рекомендації, було виготовлено чоловічі напівчеревики типу «монки» за індивідуальними параметрами споживача.

У роботі використано теоретико-аналітичні, маркетингові та експериментальні дослідження, багатофакторний експеримент, метод релаксаиії.

За допомогою комп'ютерної системи, резистивних датчиків сили FSR402 та мікроконтра Arduino Unо, розроблено прилад для вимірювання суб'єктивного зручного тиску між стопою людини та верхом взуття. Виготовлений макет-трансформер взуття, який в поєднанні з комп'ютерною установкою дозволяє оцінити рівень суб'єктивного комфорту у різних фазах ходьби та удосконалити виготовлення взуття за індивідуальним замовленням.

Представлений в роботі метод визначення тиску внутрішньої поверхні взуття на стопу споживача, з урахуванням основних антропометричних особливостей та параметрів, з використанням дослідного зразка комп'ютерної системи та «макета-трансформера» удосконалює метод виготовлення взуття на замовлення та мінімалізує строки виконання проміжного примірочного макета взуття.

Ключові слова: комфорт, індивідуальний пошив взуття, макет-трансформер, тиск, деформачія союзки.

М.М. ЛЕЩИШИН

Киевский национальный университет технологий и дизайна ORCID:0000-0003-1497-0094

\section{ОЦЕНИВАНИЕ СТЕПЕНИ КОМФОРТНОГО ДАВЛЕНИЯ ВЕРХА ОБУВИ НА СТОПУ ПОТРЕБИТЕЛЯ}

Из проведенного анализа антропометрических исследований стоп и субъективного ощущения удобства обуви показана уместность усовершенствования алгоритма моделирования обуви по индивидуальному заказу с помощью использования «макета-трансформера обуви». Данные исследования позволяют исследовать субъективные ощущения комфорта стопь в обуви, и спрогнозировать обеспечение изготовления высокого качества обуви закрытого типа по индивидуальному заказу с помощью прототипа - трансформера обуви на базе использования компьютерной установки Аrduіпо Unо. В работе исследован уровень субъективного комфортного давления верха обуви на стопу человека в статике и разных фазах ходьбы. Приведены исследования двухфакторного эксперимента зависимости параметров давления в антропометрических точках подъема и высоты пятки стопь. Получено уравнение регрессии зависимости уровня комфорта обуви. Экспериментальным путем исследованы деформационные свойства детали союзки обуви, получены линейные параметры корректировки союзки значения различных полнот колодки для изготовления обуви по индивидуальному заказу. Учитыввая полученные рекомендации, были изготовлены мужские полуботинки типа «монки» по индивидуальным параметрам потребителя.

В работе использованы теоретико-аналитические, маркетинговые и экспериментальные исследования, многофакторный эксперимент, метод релаксации. 
C помощью компьютерной системы, резистивных датчиков сильг FSR402 и микроконтра Arduino Unо разработан прибор для измерения субъективного удобного давления между стопой человека и верхом обуви. Изготовлен макет-трансформер обуви, который в сочетании с компьютерной установкой позволяет оченить уровень субъективного комфорта в разньх фазах ходьбы и усовершенствовать изготовление обуви по индивидуальному заказу.

Представленный в работе метод определения давления внутренней поверхности обуви на стопу потребителя, с учетом основных антропометрических особенностей и параметров, с использованием опытного образияа компьютерной системы и макета-трансформера совершенствует метод изготовления обуви на заказ и минимизирует сроки выполнения промежуточного примерного макета обуви.

Ключевые слова: комфорт, индивидуальный пошив обуви, макет-трансформер, давление, деформаичи союзки.

M.M. LESHCHYSHYN

Kyiv National University of Technologies and Design ORCID:0000-0003-1497-0094

\section{ESTIMATION COMFORT LEVEL OF SHOE UPPER PRESSURE ON CUSTOMER'S FOOT}

The analysis of anthropometric studies of the feet and the subjective feeling of comfort of shoes shows the appropriateness of improving the algorithm for modeling shoes to order by using a "model-transformer shoes". These studies provide an opportunity to explore the subjective feelings of foot comfort in shoes, and predict the provision of high quality indoor shoes to order with a prototype - a shoe transformer based on the computer Arduino Uno. The level of subjective comfortable pressure of the upper of the shoe on the human foot in statics and different phases of walking is investigated in the work. A study of a two-factor experiment of the dependence of pressure parameters at anthropometric points of rise and height of the heel of the foot is presented. The regression equation of the dependence of the shoe comfort level is obtained. The deformation properties of the shoe binding part were investigated experimentally, and the linear parameters of the shoe adjustment of different pad sizes for shoe production to individual order were obtained. Taking into account the received recommendations, men's half-boots of the "monki" type were made according to individual parameters of the consumer.

Theoretical-analytical, marketing and experimental researches, multifactorial experiment, relaxation method are used in the work.

Using a computer system, resistive force sensors FSR402 and a microcontractor Arduino Uno, a device has been developed to measure the subjective comfortable pressure between a person's foot and the top of a shoe. The model of the shoe transformer is made, which in combination with the computer installation allows to estimate the level of subjective comfort in different phases of walking and to improve the production of shoes to individual order.

The method of determining the pressure of the inner surface of the shoe on the foot of the consumer, taking into account the basic anthropometric features and parameters, using a prototype computer system and "model-transformer" improves the method of making shoes to order and minimizes the time of intermediate fitting model of shoes.

Keywords: comfort, individual order shoes, model-transformer, pressure, union deformation.

\section{Постановка проблеми}

3 теорії і практики взуттєвого виробництва відомо, що виготовлення взуття на рівні високої якості - основне завдання легкої промисловості, а саме виробників взуття. Практична конструкція, зручність виробу та вірно підібрані матеріали верху та низу взуття є провідними факторами при формуванні вимог міжнародних стандартів до взуття. Взуттєва промисловість щорічно вдосконалюється згідно плину тенденцій моди, розвитку техніки та науки, зміни світогляду дизайнера.

В умовах сьогодення актуальним питанням $є$ виробництво ексклюзивних одиничних виробів за індивідуальним замовленням, які підкреслюють статус замовника, його характер і вподобання. Завданням сучасних невеликих приватних взуттєвих компаній, які спеціалізуються на виробництві взуття за індивідуальним замовленням, є дослідження підготовчого і основного процесів виробництва взуття, а саме: обміру стоп і макетування моделі виробу з різних матеріалів, проектування або коригування взуттєвої колодки, формоутворення виробу під час формування взуття на колодку тощо.

\section{Аналіз останніх досліджень і публікацій}

Проблематикою вдосконалення проектування та виготовлення взуття займалося багато вітчизняних та зарубіжних вчених, серед яких: Ю. П. Зибін, R. S. Goonetilleke, В. П. Либа, Das. В., Т. А. Надопта [1 - 6]. 
Створення комфортної і зручної форми конструкції виробу є одним 3 основних етапів виробництва взуття від якісного і ретельного виконання якого залежить не тільки формостійкість $\mathrm{i}$ комфортність взуття на етапі експлуатації, а й зовнішній вигляд виробу. Відомо, що верх взуття приформовується до стопи приблизно за два-три тижні носіння [7]. Навіть при нормальному підборі матеріалів і повній відповідності формо-розмірів взуття і стопи вже при першому взуванні матеріал деталей верху взугтя з різних матеріалів розтягується. В цей час різні частини союзки розтягуються в поперечному напрямку в різних фазах ходьби від 2,9 до $10,9 \%$.

Для створення формостійкого верху слід розтягнути шкіру не більше, ніж на 7-10\%, оскільки це може призвести до швидкого руйнування верху взуття та дискомфорту стопам споживача [8; 9].

Якісне взуття повинно виготовлятись враховуючи індивідуальні антропометричні особливості споживача, навіть при мінімальних антропометричних відхиленнях стопи споживача від звичайних нормованих показників виготовлене взуття утворює дискомфорт стопам [10].

Можливість нижніх кінцівок безперешкодно здійснювати повноцінні рухи при ходьбі у взутті одне $з$ головних вимог комфортності і якості взуттєвих виробів. Ідеально комфортним взуттям можна назвати таке, в якому біомеханічні показники нижніх кінцівок при русі будуть ідентичні показникам при русі без взуття [11;12].

Виготовлення індивідуального взуття розпочинається з обмірів основних антропометричних параметрів стоп, які враховуються при проектуванні колодки. Але для створення комфортного взуття обов'язково потрібно врахувати відчуття тиску на стопу.

\section{Формулювання мети дослідження}

Метою статті є дослідити суб’єктивне відчуття комфортного тиску верху взуття на стопи споживачів, для удосконалення проектування та виготовлення взуття закритого типу для чоловіків, за індивідуальним замовленням. Дослідити деформаційні властивості шкіри для виготовлення індивідуального взуття, а саме виросток, та визначити межі коригування затягувальної кромки у деталях союзки при різних повнотах колодки.

\section{Викладення основного матеріалу дослідження}

За результатами теоретико-аналітичних, маркетингових і експериментальних досліджень в роботі представлений макет-трансформер взуття (рис. 1.a), з використанням комп'ютерної системи (рис. 1.б) на базі мікроконтролера Arduino Uno для виміру рівня суб'єктивного комфорту.

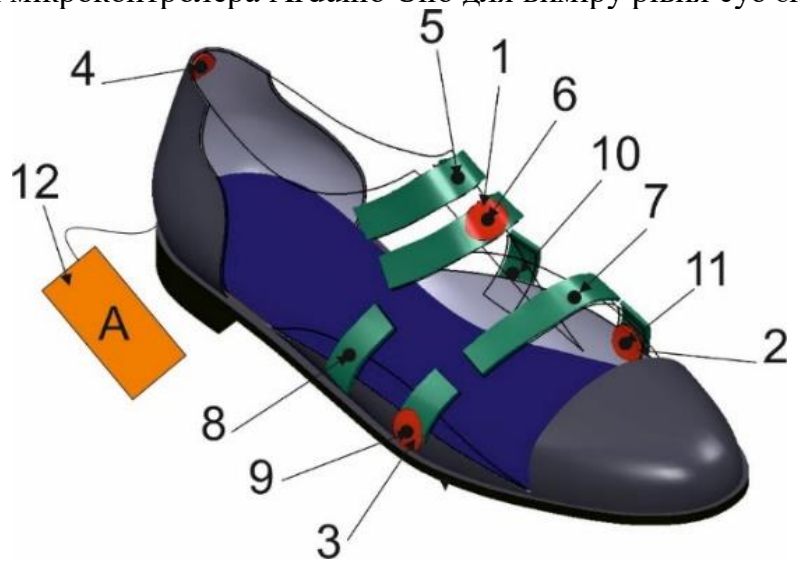

a)

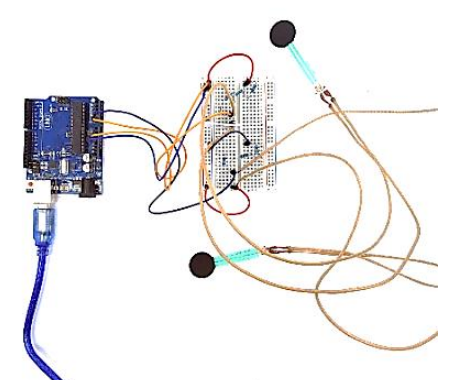

б)

Рис.1. а) - макет трансформер взуття; б) - комп'ютерна система

Виготовлений макет представлений у вигляді прототипу взуття з приклеєною підошвою, зі шкіри (верх та підклад), закритого типу, розміром 275 мм. Макет-трансформер взуття має 7 (довжиною до 100 мм) важливих антропометричних застібок.

1. - зона резистивного датчика у точці прямого підйому стопи; 2. - зона резистивного датчика у точці зовнішнього пучка стопи; 3. - зона резистивного датчика у точці внутрішнього пучка стопи; 4. зона резистивного датчика у точці висоти п’ятки стопи; 5. - висота берця; 6. - прямий підйом стопи $(0,55$ Дст); 7. - т. «кальцата» (лінія, яка з'єднує вн. та зв. пучок); 8. - середина сопи з зовнішнього боку $(0,5$ Дст); 9. - точка зовнішнього пучка $(0,68$ Дст); 10 . - середина стопи з внутрішнього боку $(0,5$ Дст); 11 . точка внутрішнього пучка (0,72 Дст), 12. - мікроконтролер Arduino UNO.

При вимірюванні тиску внутрішньої поверхні взуття на стопу, де встановлені датчики, показання приладу переводяться у величину тиску. На макеті взуття з внугрішнього простору розміщено 4 резистивні датчики сили FSR402 у позначених зонах (рис. 1 (1-4)). При натисканні на датчик в залежності від значення опору, програма використовує одну з декількох формул для розрахунку сили прикладеної до датчика та виводить $\dddot{11 і ~ ц и ф р о в е ~ з н а ч е н н я ~ н а ~ д и с п л е и ̆ ~ м о н і т о р а . ~}$ 
Ходьба - це складний циклічний рух, пов'язаний з відштовхуванням тіла від опорної поверхні і переміщенням його в просторі $[13 ; 14]$. При ходьбі розрізняють наступні фази кроку: перекат через п'яту; опора на всю стопу; перекат через передній відділ; переносний період. Результати вимірів задовільного суб’єктивного комфорту стопи у стані ходьби наведені у табл. 1.

Таблиця 1

Оцінювання зручності взуття макетом-трансформером на стопі в різних фазах ходьби

\begin{tabular}{|l|l|}
\hline Кріплення макета на стопі: & Припасовано \\
\hline Суб’єктивне відчуття комфорту, бали & 100 \\
\hline Максимальний тиск в точці виміру 1, в 3 фазі кроку, Па & 11039,1 \\
\hline Максимальний тиск в точці виміру 2, в 3 фазі кроку, Па & 9367,7 \\
\hline Максимальний тиск в точці виміру 3, в 3 фазі кроку, Па & 9922,8 \\
\hline Максимальний тиск в точці виміру 4, в 3 фазі кроку, Па & 8209,1 \\
\hline
\end{tabular}

У стані ходьби найвищий рівень комфорту спостерігається при припасованому макеті до стопи.

Для дослідження параметрів тиску внутрішньої поверхні взуття на стопу було сплановано та реалізовано двофакторний експеримент [15].

Для виявлення залежності відчуття суб'єктивного комфорту методом багатофакторного експерименту беремо до розрахунку залежність тиску в табл. 2 у третій найрепрезентативнішій фазі ходьби за даними проведеного раніше експерименту.

За верхню границю факторів $\mathrm{P}_{1}, \mathrm{P}_{4}$ прийняті такі значення: $16 \times 10^{3}$ Па; $11 \times 10^{3}$ Па. Мінімальне значення фактора $\mathrm{P}_{1}$ визначається 3 попереднього експерименту і дорівнює $8 \times 10^{3}$ Па. Мінімальне значення фактора $\mathrm{P}_{4}$ дорівнює $5 \times 10^{3}$ Па.

Експериментальні дослідження залежності комфортності стопи при ходьбі при змінному тиску у точках підйому та висоти п'ятки проводились на рівнях та з інтервалами, які наведені в табл. 2.

Рівні та інтервали зміни факторів

\begin{tabular}{|c|c|c|c|c|c|c|c|}
\hline \multirow{2}{*}{$\begin{array}{l}\text { Позна } \\
\text { чення }\end{array}$} & \multirow{2}{*}{ Фактори } & \multicolumn{5}{|c|}{ Рівні варіювання } & \multirow{2}{*}{$\begin{array}{l}\text { Інтервал } \\
\text { варіювання }\end{array}$} \\
\hline & & $-1,414$ & -1 & 0 & +1 & $+1,414$ & \\
\hline $\mathrm{X}_{1}$ & $\begin{array}{l}\text { Тиск у точці } \\
\text { прямого підйому, } \\
10^{3} \times \text { Па }\end{array}$ & 8,0000 & 9,1631 & 12,0000 & 14,8369 & 16,0000 & 2,8288 \\
\hline $\mathrm{X}_{2}$ & $\begin{array}{lrr}\text { Тиск } & \text { у } & \text { точці } \\
\text { висоти } & \text { п'ятки, } \\
10^{3} \times \text { Па } & \\
\end{array}$ & 5,0000 & 5,8723 & 8,0000 & 10,1277 & 11,0000 & 2,1216 \\
\hline
\end{tabular}

Планування експерименту проводилося з використанням ротатабельного плану Бокса [15] для двофакторного експерименту. В результаті обробки експериментальних даних одержано функцію залежності рівня комфорту взуття залежно від тиску в точці підйому $\left(\mathrm{P}_{1}\right)$ і від тиску в точці висоти п'ятки $\left(\mathrm{P}_{4}\right)$ :

$$
K=-98,6209+4,3473 P_{1}+1,1909 P_{4}+0,9375 P_{1} P_{4}-5,2616 P_{1}^{2}-6,6987 P_{4}^{2} .
$$

На рисунку 2 наведена графічна залежність рівня комфорту стопи від тиску у точці підйому та точці висоти п’ятки.

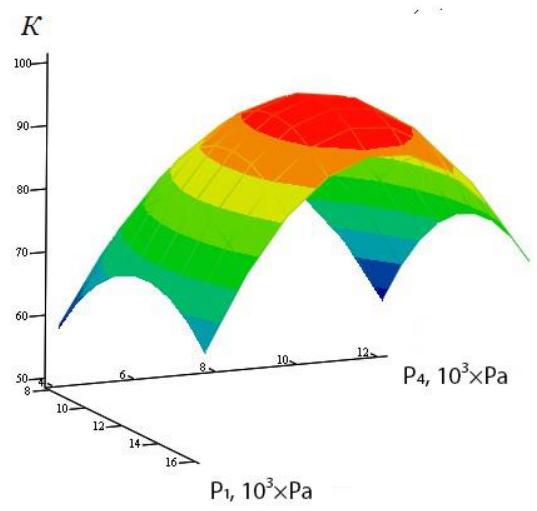

Рис. 2. Графічні залежності комфорту стопи від тиску у точці підйому та точці висоти п'ятки 
Для пошуку оптимальних параметрів тиску комфортного припасування макета до стопи в роботі застосовано метод релаксації [15]. Алгоритм методу полягає у відшукуванні осьового напряму, уздовж якого цільова функція зростає найшвидше.

Отже, після трьох циклів обчислень в результаті установили максимальне значення критерію оптимізації, яке склало 99,611, Результати пошуку зведені в табл. 3.

Таблиця 3

Знаходження максимального значення критерію оптимізації

\begin{tabular}{|c|c|c|c|}
\hline \multirow{2}{*}{ Цикл } & \multicolumn{2}{|c|}{ Фактор } & $\begin{array}{c}\text { Значення критерію } \\
\text { оптимізації } K\end{array}$ \\
\cline { 1 - 3 } & $\mathrm{P}_{1}, 10^{3} \times \Pi а$ & $\mathrm{P}_{4}, 10^{3} \times \Pi а$ & 58,601 \\
\hline 0 & 8 & 5 & 82,031 \\
\hline 1 & 8 & 7,98 & 99,503 \\
\hline 2 & 13,165 & 7,98 & 99,611 \\
\hline 3 & 13,165 & 8,251 & \\
\hline
\end{tabular}

На рис. 3 показано схему пошуку оптимуму в координатах натуральних величин.

Отже, оптимальними значеннями технологічних параметрів процесу припасування шаблона до стопи є тиск у точці підйому 13,165 кПа та точці висоти п’ятки 8,251 кПа. При цих значеннях технологічних параметрів досягається максимальне значення рівня комфорту взуття 99,611 (рис. 3).

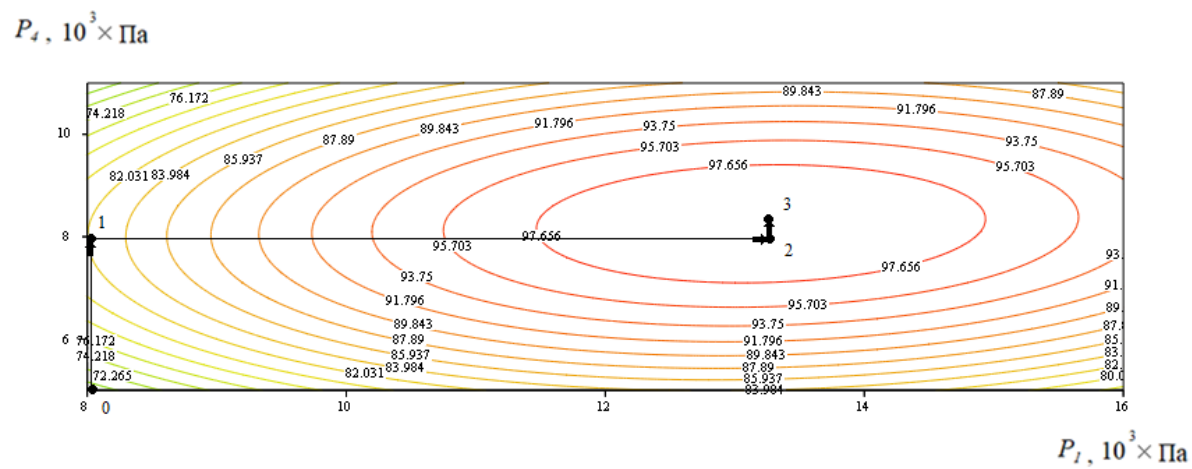

Рис. 3. Схема пошуку оптимуму при русі методом релаксації

Дослідження процесів виготовлення та випробовування експериментальних зразків взуття

Експериментальним шляхом згідно до методик представлених в ДСТУ ISO 5404:2007[16], для проведення дослідження обрано союзки чоловічих напівчеревиків 275 розміру із шкіри ВРХ (виросток, хромового дублення, товщина шкіри 1,2мм), на які нанесена допоміжна сітка ліній квадратів $20 * 20$ мм (рис. 4).
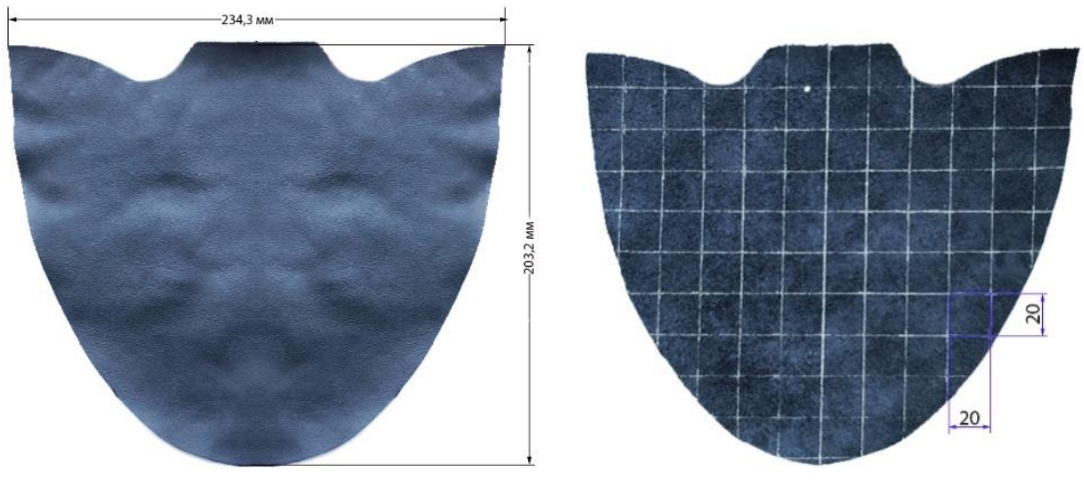

Рис. 4. Досліджувана союзка

Досліджені союзки були викроєні з різних ділянок шкіри:

- (№ 1) з чепракової частини шкіри в поздовжньому напрямі,

- $\quad$ (№ 2) друга - із чепракової ділянки в поперечному напрямі,

- (№ 3) третя викроюється у поздовжньому напрямі із крайньої зони чепракової частини шкіри припольової ділянки. Всього 18 зразків [17; 18]. 
3 бахтарм'яної сторони деталі наноситься сітка ліній, що утворює квадрати розміром 20×20 мм; поперечні лінії (перпендикулярні лінії перегину деталі) нумерують арабськими цифрами, поздовжні лінії нумерують з внутрішньої і зовнішньої сторін союзки римськими цифрами (рис. 5).

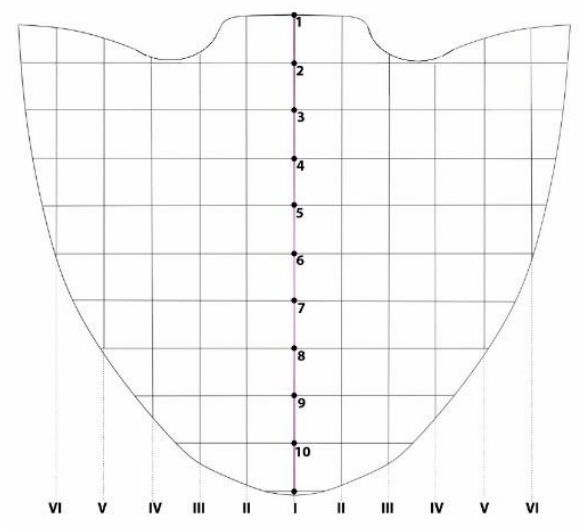

Рис. 5. Графічне зображення досліджуваних зразків союзки

Досліджувані союзки формувалися на затяжній машині ЗНК-3-О на клей-розплав за допомогою кліщів і пластин (скобів). Робочий тиск в гідросистемі, МПа - 5, температура затяжних пластин $60-$ 1200С. Потрібно враховувати той факт, що рухи затяжної машини $є$ однаковими за частотою відтворюваності руху та прикладеним до заготовки зусиллям. Після процесу затягування зразки витримують добу на колодці та потім знімають. Вимірювання деформації матеріалів по загальній довжині ліній і сторонам квадратів виконувались після зняття союзок 3 колодки через 40 хв штангенциркулем з точністю до 0,1 мм.

По формулі (2) визначено величину деформації по лініям зразка

$$
E=\left(l-l_{0}\right) / l_{0}
$$

де $\quad l_{0}$ - початкова довжина лінії (20 мм);

$l$ - довжина ліній після випробувань, мм.

Значення вимірювання розмірів кожного квадрату дев'яти зразків деталей першого варіанту (на існуючій колодці) та дев’яти зразків другого варіанту (на коригованій колодці накладкою в антропометричній зоні підйому стопи) після деформації усереднювали і враховували зміни при відхиленнях в $\pm 2,5 \%$ і більше від початкового розміру.

При формуванні спостерігаємо нерівномірну деформацію досліджуваного зразка в різних частинах. При поперечній деформації (рис. 6): у носковій частині деформація досягає 2,5 - $8 \%$, у зоні підйому 2 -5,5\%, у зоні близькій до устілкової грані колодки досягає 5,5\%.

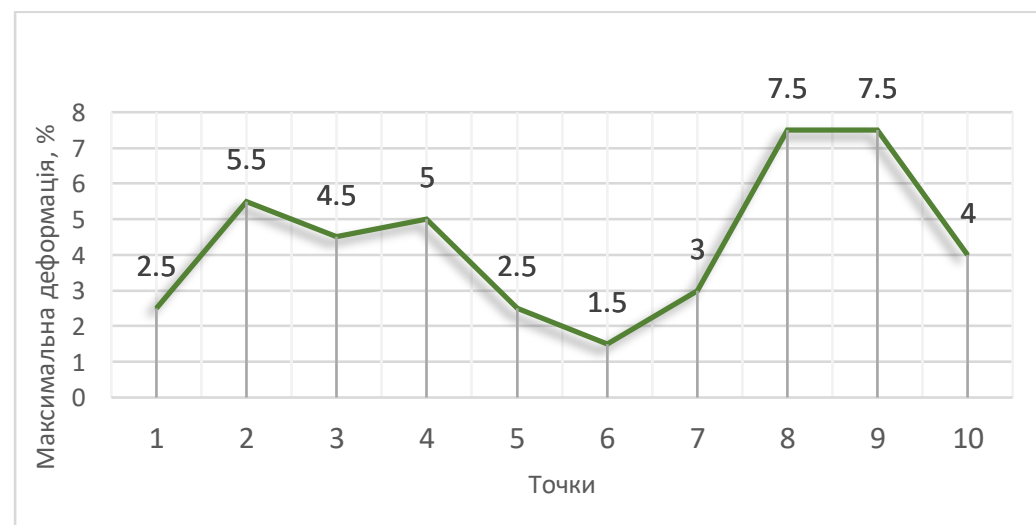

Рис. 6. Графік поперечної деформації досліджуваної союзки на існуючій колодці

Аналізуючи рисунок 7, можна спостерігати суттєву деформацію досліджуваної союзки, яка формувалася на кориговану колодку в зоні підйому. 
Так, в носковій частині деталі деформація досягає 8\%, у зоні підйому 13,5\%, у частині близькій до устілкової грані колодки 6\%. Найбільшої деформації досліджувана союзка на коригованій колодці зазнала у поперечному напрямку відповідно зоні підйому стопи.

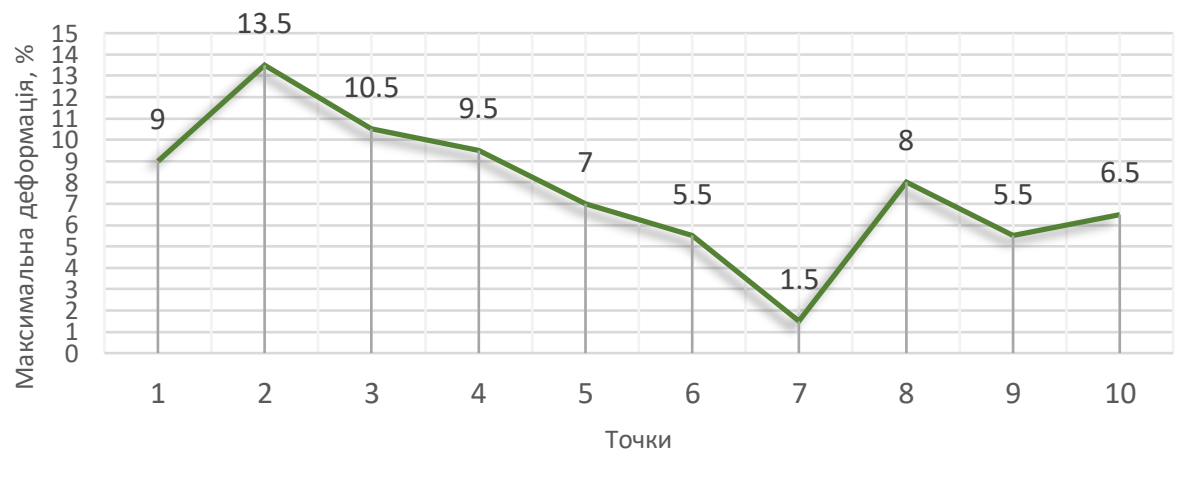

Рис. 7. Графік поперечної деформації досліджуваної союзки на коригованій колодці

Визначення зміни лінійних розмірів досліджуваних деталей визначалось способом порівняння союзок після формування на існуючій колодці та коригованій колодці індивідуальною накладкою (рис. 8.б), шляхом сканування деформованих деталей союзок, та за допомогою графічного редактора CorelDRAW дані зображення деталей порівнювалися зі збереженим масштабом. У такий спосіб, спостерігаємо реальні лінійні зміни поперечної деформації порівнювальних союзок у зоні підйому стопи, де і була зафіксована індивідуальна накладка на колодці (рис. 8.б).
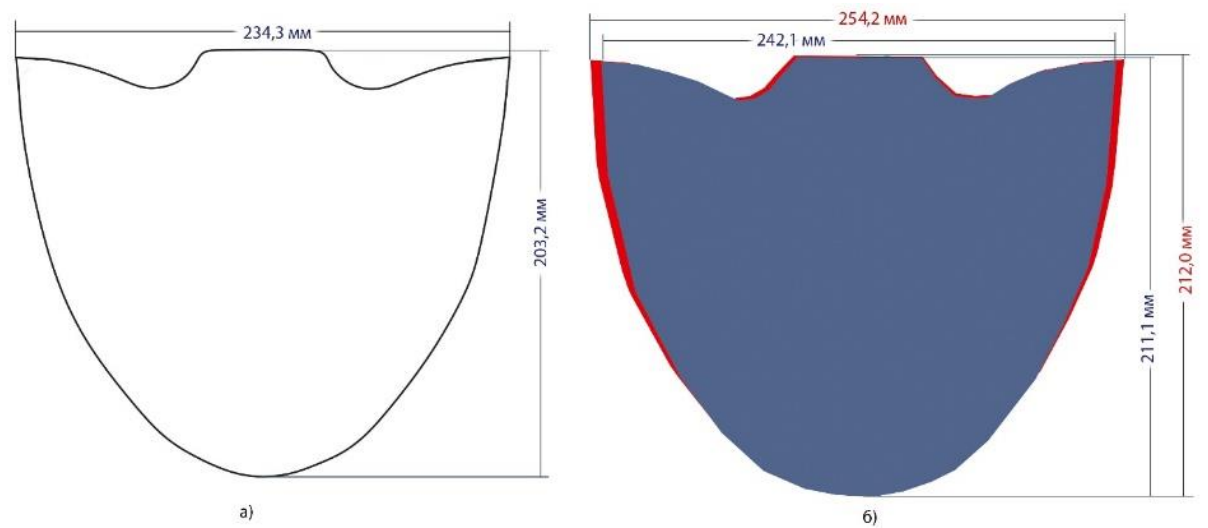

Рис. 8. Зміна розмірів союзок при формуванні деталей на колодках

Отже, експериментальним шляхом було виявлено деформацію деталей при формуванні. Різниця досліджуваних союзок (із шкіри виросток) після формування на існуючу та кориговану колодку в поперечному напрямі (поперечні лінії 1-6, рис. 5 та рис. 8.б) в зоні підйому та пучків досягає 12,1мм. Ця різниця складає 5 \% від ширини заготовки, розрахованої для стандартної заготовки. Отже, для досягнення величин деформації союзки при використанні колодки 3 накладкою, потрібно збільшити поперечні розміри заготовки у зоні підйому та пучків на 5 - $6 \%$.

Враховуючи експериментальне дослідження деформації союзок було виготовлено чоловічі напівчеревики типу «монки» (рис. 9), 275 розміру, на кориговану колодку індивідуальною накладкою, зі шкіри виросток, хромового методу дублення, товщина матеріалу верху 1,2 мм. 


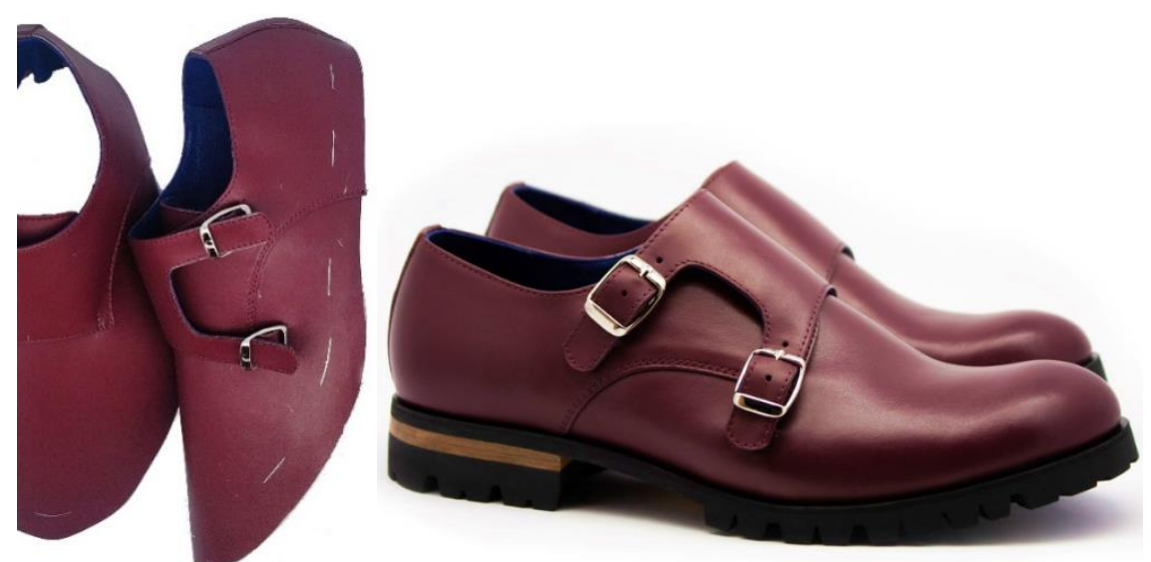

Рис. 9. Виготовлені чоловічі напівчеревики типу «монки»

\section{Висновки}

Рекомендований в роботі метод вимірювання сили тиску верху взуття на стопу людини за допомогою комп'ютерної установки та запропонованого макета-трансформера взуття дозволяє підвищити конструкторсько-технологічну підготовку для виготовлення взуття за індивідуальним замовленням.

У підсумку роботи, щодо визначення сили тиску верху взуття на стопу людини, наведені фіксовані значення комфортного тиску в основних антропометричних точках у стані стояння та ходьби людини.

Наведено результати дослідження впливу параметрів тиску у антропометричних точках тиску підйому та висоти п’ятки стопи. Одержано рівняння регресії залежності рівня комфорту взуття залежно від тиску в точці підйому $\left(\mathrm{P}_{1}\right)$ і від тиску в точці висоти п'ятки $\left(\mathrm{P}_{4}\right)$.

Для виготовлення якісного та комфортного взуття необхідно враховувати всі антропометричні особливості стопи, особливо при проектуванні нової моделі для замовника. При незначних відхиленнях (до 5 мм) антропометричних параметрів стопи замовника від існуючої колодки в зонах підйому та пучків, для виготовлення взуття необхідно обирати достатньо еластичні шкіри, які своєю тягучістю дозволяють не коригувати вже існуючі шаблони деталі союзки. В іншому випадку, необхідно враховувати різницю параметрів колодки від окремої стопи замовника, при конструюванні та виготовленні моделі взуття додаючи необхідний припуск по затяжній кромці у визначених зонах, щоб запобігти швидкому руйнуванню шкіри та втрати естетичного вигляду виробу.

\section{Список використаної літератури}

1. Зыбин Ю.П. Конструирование изделий из кожи / Ю.П. Зыбин, В.М. Ключникова, Т.С. Кочеткова, В.А. Фукин - М: Легкая и пищевая промышленность, 1982. 264c.

2. Чертенко Л.П., Тукало Н.М., Гаркавенко С.С.: Розробка оригінального дизайну для розробки функцій 3D-моделі, Технологія та дизайн 26(1), 2018, С.1-12, Режим доступу: http://nbuv. gov.ua/UJRN/td_2018_1_8

3. Goonetilleke, R. S., 1998, Designing to Minimize Discomfort. Ergonomics in Design, 6(3), pp. 12.19.

4. Лыба В.П. Теория и практика проектирования комфортной обуви: дис. доктора техн. наук: 05.19.06 / Лыба Владимир Петрович. М., 1996. 314 с.

5. Надопта Т.А. Розробка методу проектування деталей верху взуття на основі аналітичної моделі прототипу : дис. ... канд. техн. наук : 05.18.18 / Надопта Тетяна Анатоліївна. - Хмельницький, 2013. $214 \mathrm{c}$.

6. Das. B. Designing for Comfort: A Footwear Application/ Das B., Karwowski W., Mondelo P., Mattila M.. - Hong Kong University of Science and technology Clear Water Bay. 2001.

7. ДСТУ 3115-95 Шкіра для швейних виробів. Загальні технічні умови.

8. Лиокумович В. Х. Конструирование обуви по индивидуальным заказам / В. Х. Лиокумович. М. : Легпищепром, 1984. 112 с

9. Коновал В. П. Універсальний довідник взуттєвика: навчальний посібник / В. П. Коновал, С. С. Гаркавенко, Л. Т. Свістунова. Київ : Лібра, 2005. 720 с.

10. Hurschler C., Vanderby R., Martinez D.A.: Mechanical and biochemical analyses of tibial compartment fascia in chronic compartment syndrome, Ann Biomed Eng. 1994, 22:272-9, DOI: 10.1007/bf02368234

11. Kura H., Luo Z.P., Kitaoka H.B.: Mechanical behavior of the Lisfranc and dorsal cuneometatarsal ligaments, in vitro biomechanical study, J Orthop Trauma. 2001, 15:107-10, DOI: 10.1097/00005131- 


\section{0- 00006}

12. Jahss M.H., Kummer F., Michelson J.D.: Investigations into the fat pads of the sole of the foot, Foot \& Ankle, 1992. Vol. 13, № 5. pp. 227-232

13. Уткин В. Л. Биомеханика физических упражнений: учеб. пособие для студентов фак. физ. воспитания пед. ин-тов и для ин-тов физ. культуры по спец. № 2114 «Физ. воспитание». М.: Просвещение, 1989. 210.с

14. Горбачик В. Е. Основы анатомии, физиологии, антропометрии и биомеханики : учебное пособие / В. Е. Горбачик. - Витебск : УО «ВГТУ», 2011. 125 с.

15. Тихомиров В.Б. Планирование и анализ эксперимента. М,: Легкая индустрия, 1974. $262 \mathrm{c}$.

16. ДСТУ ISO 5404:2007 Шкіра. Фізико-механічні випробування.

17. Козарь О.П. Оцінка релаксаційно-деформаційних характеристик шкір для верху взуття, наповнених природними мінералами / О.П. Козарь, О.Р. Мокроусова, В.П. Коновал // Вісник Київського національного університету технологій та дизайну. 2013. №4. с.107-115.

18. Kozar O.P. Deformation characteristics of genuine leather, manufactured using natural minerals / O.P. Kozar, O.R. Mokrousova, V.P. Konoval // Proceedings of the 13 th International Conference «Baltic Polymer Symposium», (Trakai, Lithuania, 18-21 September 2013)/R. Makuska. Vilnius University, 2013. p.141.

\section{References}

1. Zybin Yu.P., Klyuchnikova V.M., Kochetkova T.S., Fukin V.A. (1982). Konstruirovanie izdeliy iz kozhi [Leather goods design]. Moscow. [in Russian].

2. Chertenko L.P., Tukalo N.M., Garkavenko S.S. (2018): Rozrobka oryhinal'noho dyzaynu dlya rozrobky funktsiy 3D-modeli [The development of the original design for the development of 3D model functions], Technology and Design. [in Ukrainian].

3. Goonetilleke, R. S. (1998). [Designing to Minimize Discomfort]. Vol. 6(3), pp. 12.19. [in UK].

4. Lyba V.P. (1996) Teoriya i praktika proektirovaniya komfortnoy obuvi [Theory and practice of designing comfortable footwear] Doctor's thesis. Moscow. [in Russian].

5. Nadopta T.A. (2013). Rozrobka metodu proektuvannia detalei verkhu vzuttia na osnovi analitychnoi modeli prototypu [Development of a method for designing shoe uppers based on an analytical model of a prototype] Ph.D thesis. [in Ukrainian].

6. Das B., Karwowski W.,Mondelo P., Mattila M. (2001). [Designing for Comfort]. Hong Kong University of Science and technology Clear Water Bay. [in Hong Kong].

7. DSTU ISO 5404: 2007. Shkira. Fizyko-mekhanichni vyprobuvannia. [Leather. Physico-mechanical tests].

8. Lyokumovych V. Kh. (1984). Konstruyrovanye obuvy po yndyvydualnыm zakazam. [Designing of footwear by individual orders]. [in Russian].

9. Konoval V. P., Harkavenko S. S., Svistunova L. T. (2005). Universalnyi dovidnyk vzuttievyka: navchalnyi posibnyk. [Universal shoemaker's guide: a textbook].. [in Ukrainian].

10. Hurschler C., Vanderby R., Martinez D.A. (1994): [Mechanical and biochemical analyses of tibial compartment fascia in chronic compartment syndrome]. [in USA].

11. Kura H., Luo Z.P., Kitaoka H.B.( 2001). [Mechanical behavior of the Lisfranc and dorsal cuneometatarsal ligaments, in vitro biomechanical study]. [in USA].

12. Jahss M.H., Kummer F., Michelson J.D.: Investigations into the fat pads of the sole of the foot, Foot \& Ankle, 1992. Vol. 13, № 5. pp. 227-232

13. Utkin V. L. (1989). Biomekhanika fizicheskikh uprazhneniy [Exercise biomechanics]. Fiz. Vospitanie - Physical Education. Moscow. [in Russian].

14. Gorbachik V. E. (2011). Osnovy anatomii, fiziologii, antropometrii i biomekhaniki [Fundamentals of Anatomy, Physiology, Anthropometry and Biomechanics]. [in Belarus].

15. Tikhomirov V., B.( 1974). Planirovanie i analiz eksperimenta. [Planning and analysis of the experiment]. Light Industry. Moscow. [in Russian].

16. DSTU ISO 5404:2007 Shkira. Fizyko-mekhanichni vyprobuvannia [Skin. Physico-mechanical tests].

17. Kozar O.P., Mokrousova O.R., Konoval V.P. (2013). Otsinka relaksatsiino-deformatsiinykh kharakterystyk shkir dlia verkhu vzuttia, napovnenykh pryrodnymy mineralamy. [Evaluation of relaxation and deformation characteristics of leather for shoe uppers filled with natural minerals]. [in Ukrainian].

18. Kozar O.P., Mokrousova O.R., Konoval V.P. (2013). [Deformation characteristics of genuine leather, manufactured using natural minerals]. [in Ukrainian]. 